\title{
Shingles in a pediatric healthcare provider: Can patient care continue?
}

\author{
Lynnette Mazur*, Ethan Reznicek and Susan Wootton \\ McGovern Medical School, 6431 Fannin, Suite JJL 495, Houston, Texas, USA
}

\section{Introduction}

Herpes zoster, also known as shingles, results from a reactivation of latent Varicella zoster virus (VZV) within sensory ganglia and is characterized by a painful unilateral vesicular rash that affects one or more dermatomes. Reactivation occurs in one of three persons and results in an estimated million cases a year in the United States [1]. Although it is more common in the elderly this student had two risk factors for HZ. First, he contracted chickenpox in the first year of life, a time when there is a poor immune response to the virus and second, natural infection carries a higher risk for $\mathrm{HZ}$ than vaccination [2]. This may be attributed to the weakened ability of the attenuated virus to access the sensory nerves which makes it less likely to establish latency and reactivate [3].

\section{Case}

While on his pediatric rotation, a third-year medical student developed pain and itching over his left hip. A week later he developed a vesicular rash localized to the T12 dermatome and was diagnosed with herpes zoster (HZ) (Figures 1 and 2). His past medical history included chickenpox at 10 months of age. Upon admission to medical school his varicella zoster immunoglobulin $G$ titer was positive; a repeat titer obtained in clinic was also positive. His symptoms improved with valacyclovir and the rash resolved over the next two weeks. At the time of his diagnosis he questioned whether he was able to continue his rotation.

Infection with VZV begins with the inhalation of infectious particles or by mucosal inoculation with infectious vesicular fluid from

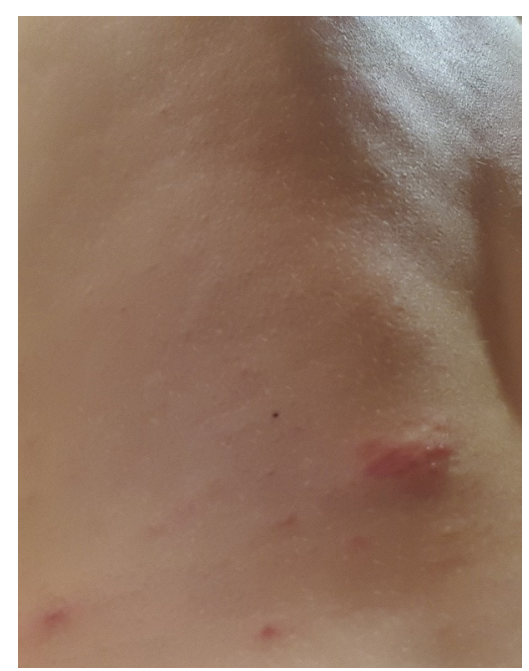

Figure 1. Shingles on left flank.

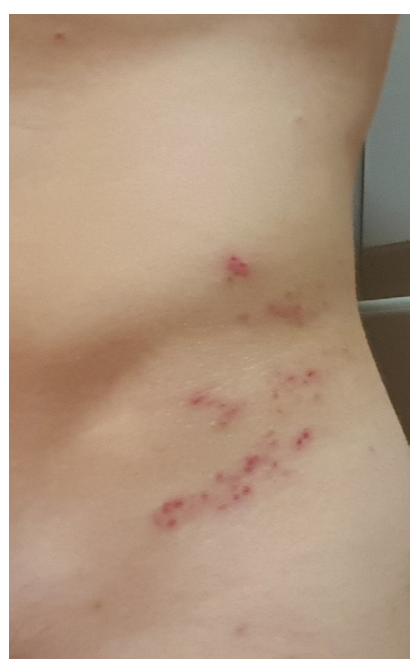

Figure 2. Shingles left flank.

Table 1. Recommended CDC work restrictions for health care workers with HZ

\begin{tabular}{|l|l|}
\hline Presentation & Recommendation \\
\hline Localized in a healthy individual & $\begin{array}{l}\text { Cover the lesions and avoid high-risk } \\
\text { patients until all the lesions have dried and } \\
\text { crusted. }\end{array}$ \\
\hline $\begin{array}{l}\text { Generalized or localized in an } \\
\text { immunosuppressed individual }\end{array}$ & $\begin{array}{l}\text { No patient contact until all lesions have } \\
\text { dried and crusted }\end{array}$ \\
\hline Postexposure in susceptible personnel & $\begin{array}{l}\text { No patient contact from } 10 \text { days after the } \\
\text { first exposure until 21 days (28 if given } \\
\text { VZIG) after last exposure. If varicella } \\
\text { occurs, no patient contact until all lesions } \\
\text { have dried and crusted. }\end{array}$ \\
\hline
\end{tabular}

an individual with VZV or HZ. The host's first response is mediated by the innate immune system through antiviral cytokines and activation of natural killer (NK) cells [4]. NK cells produce interferons which enhance the production of antigen-specific T cells. VZV also induces the production of antibodies that interfere with VZV replication and, with compliment, function in antibody-mediated cytotoxicity [5]. However, as most of the infection is cell-associated, humoral immunity is a less important defense mechanism. This is highlighted when patients with agammaglobulinemia experience uncomplicated varicella infections

${ }^{\star}$ Correspondence to: Lynnette Mazur, McGovern Medical School, 6431 Fannin, Suite JJL 495, Houston, Texas, USA, Tel: (713) 873-6861, (713) 873-6886; E-mail: Lynnette.j.mazur@uth.tmc.edu

Received: February 01, 2019; Accepted: February 15, 2019; Published: February 19,2019 
and when children with $\mathrm{T}$ cell immunodeficiencies develop fulminant varicella despite an antibody response [6].

Meanwhile, during the 10 to 21 days incubation period, VZV is proliferating in the oropharynx, invading $\mathrm{T}$ cells of the blood, and disseminating to other organs [4]. It avoids destruction by inhibiting major histocompatibility classes I and II while it travels to the skin in the early stages of infection [6]. The viral envelope glycoproteins play an important role in this process. While the envelope is unnecessary for cell-to-cell transmission, it is required for spread from person-toperson and entry into the nervous system. After T cells carry the virus to the skin the envelope redevelops and travels to sensory nerves. The envelope's mannose 6-phosphate binds with these receptors in the sensory nerves [4].

\section{Discussion and conclusion}

It is unclear what leads to reactivation of the virus but diminished $\mathrm{T}$ cell responses to VZV antigens in older and immunocompromised persons correlate with an increased susceptibility to HZ. During reactivation, $\mathrm{T}$ cell responses increase quickly, including CD4, CD8, and NK cells. Enhanced VZV T cell immunity persists for at least 3 years after $\mathrm{HZ}$ and may explain why repeat episodes of $\mathrm{HZ}$ are rare [7]. Furthermore, as in our patient, reactivation is not associated with decreasing titers of VZV antibodies.

The diagnosis is usually based on clinical suspicion once the rash appears, but laboratory testing may be useful in cases with early or less typical presentations. Polymerase chain reaction can detect VZV DNA rapidly and sensitively. Older tests such as direct fluorescent antibody and Tzanck smear are no longer recommended due to limited sensitivity and specificity respectively [8].

Because it is highly contagious the CDC recommends certain isolation precautions for health care workers with shingles (Table 1). Based on these recommendations, the student was advised to cover his lesions and avoid contact with unvaccinated infants and children until all his lesions had crusted over. However, new evidence may challenge these recommendations.

A landmark study showed that both $\mathrm{HZ}$ and sporadic varicella result in secondary cases of varicella [9]. During a seven-year surveillance period of schools and day care facilities in Philadelphia 648 cases of secondary varicella (defined as occurring 10-21 days after a case of $\mathrm{HZ}$ or sporadic varicella) were identified. Eighty-four (13\%) cases resulted from exposure to $27 \mathrm{HZ}$ cases and $564(87 \%)$ cases resulted from exposure to 205 varicella cases. Additionally, individuals with rashes on the trunk, an area usually covered by clothing, had the same probability of transmission as those with rashes on other areas. And, most individuals who contracted varicella had $>1$ dose of the varicella vaccine. These findings contradict the assumption that coverage of skin lesions and varicella vaccination prevent VZV transmission and subsequent infection.
Fortunately, both chickenpox and shingles are vaccine-preventable illnesses. In 1995 the CDC's Advisory Committee on Immunization Practices recommended one dose of the varicella vaccine for children $\geq$ 1 year of age. In 2006, with evidence that recipients of two doses were three times less likely to have breakthrough varicella as compared with recipients of one dose $(2.2 \%$ vs $7.3 \%)$, they recommended a second dose at age 4 years. That same year they also recommended a single dose of the HZ vaccine (Zostavax) to adults $\geq 60$ years irrespective of a history of chickenpox or shingles. In October 2017, the ACIP recommended a new vaccine, Shingrix, for the prevention of shingles in immunocompetent adults $\geq 50$ years, even in individuals who previously received Zostavax [10]. Although it requires two doses, it shows $>90 \%$ efficacy in the prevention of shingles when compared to the older vaccine's efficacy of $70 \%$ [10].

In conclusion, exposure to persons with $\mathrm{HZ}$ may play a prominent role in VZV transmission. In a time of vaccine-hesitant parents, a rise in parents who claim non-medical exemptions for vaccination, and an increasing elderly population with waning immunity, healthcare providers must promote and provide these immunizations for both their pediatric and adult patients. And, providers with $\mathrm{HZ}$ should be familiar with the CDC recommendations for work restrictions.

\section{References}

1. Johnson BH, Palmer L, Gatwood J, Lenhart G, Kawai K, et al. (2015) Annual incidence rates of herpes zoster among an immunocompetent population in the United States. BMC Infect Dis 15: 502. [Crossref]

2. Baba K, Yabuuchi H, Takahashi M, Ogra PL (1986) Increased incidence of herpes zoster in normal children infected with varicella zoster virus during infancy: community-based follow-up study. J Pediatr 108: 372-377. [Crossref]

3. Chen JJ, Zhu Z, Gershon AA, Gershon MD (2004) Mannose 6-phosphate receptor dependence of varicella zoster virus infection in vitro and in the epidermis during varicella and zoster. Cell 119: 915-926. [Crossref]

4. Gershon AA, Gershon MD (2013) Pathogenesis and current approaches to control of varicella-zoster virus infections. Clin Microbiol Rev 26: 728-743. [Crossref]

5. Arvin AM, Koropchak CM, Williams BR, Grumet FC, Foung SK (1986) Early immune response in healthy and immunocompromised subjects with primary varicella-zoster virus infection. J Infect Dis 154: 422-429. [Crossref]

6. Abendroth A, Kinchington PR, Slobedman B (2010) Varicella zoster virus immune evasion strategies. Curr Top Microbiol Immunol 342: 155-171. [Crossref]

7. Weinberg A, Levin MJ (2010) VZV T cell-mediated immunity. Curr Top Microbiol Immunol 342: 341-357. [Crossref]

8. Diagnosis \& Testing. Available from: https://www.cdc.gov/shingles/hcp/diagnosistesting.html

9. Viner K, Perella D, Lopez A, Bialek S, Newbern C, et al. (2012) Transmission of varicella zoster virus from individuals with herpes zoster or varicella in school and day care settings. J Infect Dis 205: 1336-1341. [Crossref]

10. Vaccines \& Immunizations. Available from: www.cdc.gov/vaccines

Copyright: (C2019 Mazur L. This is an open-access article distributed under the terms of the Creative Commons Attribution License, which permits unrestricted use, distribution, and reproduction in any medium, provided the original author and source are credited. 